\title{
Should 1974 be considered a watershed year in the economic history of the world?
}

\author{
G. Jan Hupkes \\ School of Business Leadership, University of South Africa
}

Inaugural lecture

The early 1970 s marked a turning point in mankind's economic fortunes and the author takes 1974 as an 'artificial' vantage point from which to look back, but also forward. Several forces led to the shocks of the seventies: the breaking down in the discipline of the international payments system, rising inflation, the oil crisis, the West's loss of strategic military initiative to the East. The author outlines what ought to be done to improve the economic outlook for the 1980s: The international payments system must be placed on a more stable and disciplined footing, inflation must be controlled by balancing of national budgets, the energy crisis must be contained by reduction of oil consumption via the price mechanism. In South Africa the economic watershed year was 1976; two years later than that of the world economy in general. Since then a policy of strict financial discipline has led to a record surplus in balance of payments, which together with new emphasis on the importance of the free market mechanism and increasing energy self-sufficiency, pro mises a better economic future for South Africa than for many other countries.

S. Afr. J. Bus. Mgmt. 1980, 11:45-49

Die vroee 1970s was 'n keerpunt in die mensdom se ekonomiese lotgevalle en die skrywer neem 1974 as 'n 'kunsmatige' uitsigpunt vanwaar hy terug kyk, maar ook vorentoe. Verskeie magte het gelei tot die skokke van die sewentigs: die aftakeling van die dissipline van die internasionale betalingstelsel, stygende inflasie, die oiliekrisis, en die Weste se afstand van strategiese militêre inisiatief aan die Ooste. Die skrywer dui aan wat gedoen moet word om die ekonomiese vooruitsigte vir die 1980s te verbeter: Die internasionale betalingstelsel moet op 'n meer stabiele en gedissiplineerde grondslag geplaas word, inflasie moet deur die balansering van nasionale begrotings beheer word, die energiekrisis moet via die prysmeganisme deur verminderde olieverbruik beteuel word. In Suid-Afrika was die ekonomiese waterskeidingsjaar 1976; twee jaar later as die van die wêreldekonomie in die algemeen. Sedertdien het 'n beleid van streng finansièle dissipline gelei tot 'n rekord surplus op die beta. lingsbalans, wat saam met nuwe klem op die belangrikheid van die vrye markmeganisme en toenemende energie-selfvoorsiening, 'n beter ekonomiese toekoms vir Suid-Afrika as vir baie ander lande beloof.

S. Afr. Tydskr. Bedrysl. 1980, 11: $45-49$
I am convinced that the early seventies marked a turning point in mankind's economic fortunes, and have chosen this as the theme for this discussion.

My conviction on this central issue is not affected by the many doubts and uncertainties accompanying a number of the interrelated issues involved. When exactly did this turning point occur? Should it be considered as a natural phase in a continuous long term wavelike movement, like the proponents of the Kondratief theory would like us to believe? Or does it represent a more abrupt or permanent shift - or structural change - from one set of economic circumstances to another, where the whole ball game changes?

Herman Kahn, in his refutation of the rather dismal projections of the Club of Rome's 'Limits to Growth', had this to say about an approach to the methodology of using past history to project future trends: 'Often contemporary issues are not fully understood until they have become history and can be seen in historical context. To some extent futurology can furnish such a context now by giving us an artificial vantage point from which to look backward; examined in this long term perspective, current issues look quite different and can be better comprehended'.'

I have chosen 1974 as my artificial vantage point; not only to look back, but also to look forward. Many others may disagree with the choice of this particular year. Why, for instance, not the year 1971? Remember in February of that year we had the famous (?) Teheran Agreement from which OPEC's real power started to emerge and indirectly resulted, six months later, in the formal scrapping of the convertibility of the dollar into gold? Was this not the start of the rot?

But the year 1974 also has its claim to fame, if that is the right word. It stood out as a period when quite a number of chickens came home to roost.

On the economic front the higher oil prices started to bite, causing the severest post-war economic recession in the West, the numbers of unemployed became comparable with the depression of the early thirties. Inflation shot up to unthinkable heights. The word slumpflation was coined. Stockmarkets crashed and bankruptcies soared. Another even more unthinkable thing happened. Two fairly large banks, The Franklin National in New York and Bankhaus Herstadt in Germany crashed. Pan Am announced it was in severe financial straits. Britain went onto a three day working week and in the United 
States Mr William Simon ordered the printing of petrol rationing coupons. Naturally this resulted in the first ever hijacking of a gasoline tanker ... .

There were quite a number of changes in heads of states on the international scene, some only to put up an ephemeral appearance. More or less in order of sequence they were: Harold Wilson in Britain, Spinola in Portugal, Rabin in Israel, Giscard D'Estaing in France, Helmut Schmidt in Germany, Isabel Peron in Argentinia, Juan Carlos in Spain and even in the United States an impeachable president was discovered.

For the economist 1974 furthermore stood out as the year when traditional and comfortable economic theories, and convictions were rudely shaken. Ivory tower beliefs that a depression of the severity of the early thirties could be averted by following a policy of demand management were rudely shattered by economic realities. Suddenly the roaring sixties became the raving seventies. Some blamed the Arabs. Others turned to deeper soulsearching.

It is the purpose of this paper to attempt to look, with the wisdom of hindsight, at those interrelated forces in the economy that, inexorably, (and partially by the way in which they were managed) culminated in the state of affairs which we have today.

\section{Forces leading to the shocks of the seventies}

Economics is not an exact science and it is not possible to control experimental conditions, as one does in scientific laboratories. It is very difficult, but nevertheless necessary, to relate cause and effect, especially when there often is an interrelationship or two-way-flow between cause and effect.

By separately discussing below a number of factors which have contributed to our present day economic world, one runs the risk of analysing these in isolation. On the other hand, when these are all grouped together, the risk of allowing detail to swamp the central issues becomes even greater. These caveats should be borne in mind, as well as the fact that the forces listed below are not necessarily in sequence of importance. One simply had to start somewhere.

The breaking-down of the discipline of the international payments system

The three main objectives of the ideal international payments system would be:

- To allow national economies to grow at optimal, sustainable rates.

- To put realistic market values on national currencies.

- To maintain stability that encourages world trade and exploits comparative trade advantages to the full.

Serious deficiencies in the Bretton Woods Agreement, which formed the basis of the post war international payments system, impaired the achievement of these goals and contributed to the many malaises we are suffering from today.

A brief, and therefore incomplete, resumé is necessary:

The Bretton Wonds negotiators were faced with severe imbalances in the world economies towards the end of
World War II and naturally looked upon the dollar, and to a lesser extent upon sterling, as the pillars to which other war-torn currencies should be tied. The dollar was again anchored to gold (at $\$ 35$ a fine ounce) and a system of cross rates for all currencies was worked out (which gave each national currency a gold content). The IMF with its quota system was established supplying a reserve pool of short-term borrowings for temporary payments imbalances. Changes in currency values could only be effected when the experts at the IMF were satisfied that a fundamental disequilibrium was apparent.

No country could therefore unilaterally change its exchange rate to suit its own domestic purposes, and the discipline in the system showed up in the balance of payments. At that stage of history a deficit on the balance of payments was still considered as a sign of overindulgence or bad domestic management of the economy. Standby credits from the IMF were available, provided the country in question was willing to put its own economic house in order. The IMF thus acted as a financial INTERPOL, imposing stiffer conditions for subsequent standby credits.

The wise men at Bretton Woods, however, failed to foresee the virtual explosion in world trade that would take place in the following two decades, as well as the sharp swings in balances of payments that would occur. The available 'reserves' created through the IMF were simply not enough to finance such fluctuations, despite much patchwork, for example the Basle Agreement and later the advent of SDR's.

However, another source of world liquidity was readily available - deficits on the United States' balance of payments. Uncle Sam's printing press started flooding the world's financial markets and for a while nobody really minded, and for two very good reasons. Firstly: USA deficits were doing 'good' things at that time. Had they not helped to rebuild the war devastated economies of the west and enabled these countries to run up the surpluses they so desparately needed? And, secondly: Were these little pieces of paper, carrying the inscription 'In God We Trust' not more than covered by huge quantities of gold at Fort Knox? At a pinch, anybody could take his $\mathbf{3 5}$ greenbacks back to the States and demand an ounce of fine gold!

For quite a while the USA did not have to worry about its deficits or the discipline of the international payments system. Nobody shouted: 'Dollar go home!' Until some nasty financiers (especially the French) started doing sums during the Vietnam era and decided gold was better than greenbacks. Various measures were taken to counteract the subsequent gold drain from the USA. In 1962 the Gold Pool was established which tried to control the sales of dollars against gold and this was followed in 1968 by the two-tier gold market. But there was no escape from reality and by 1971, when the US balance of payments culminated in a deficit of $\$ 50$ billion, President Nixon closed the stable door. On August 15, 1971, convertibility between the dollar and gold was formally terminated. Some quarters maintain that he acted on advice from the Pentagon. Since then the dollar officially also became a mere piece of paper, its value depending on a complex interrelationship of economic variables.

In discussing the rise and fall of the dollar, we have 
skipped quite a number of happenings on the international payments front. The original idea of the Bretton Woods Agreement regarding fixed parties started to crumble in the middle sixties with countries like France openly flouting the rules. A new specie of profiteers developed: The international currency speculators, with Central Banks as their main targets or victims. When the latter decided to defend a currency at a given level, the speculators would pitch in at full might and offload that currency until they forced the defenders to capitulate. They knew they were on to a sure thing because call funds at their disposal were considerably in excess of the combined reserves of all Central Banks! (As an aside I may mention that during the course of my work in the early seventies I often spoke to this speculator community. One assured me that his operation was 'as easy as taking candy from a child'.)

Ironically, of course, these speculating funds originated from the self-same deficits on the US balance of payments. Monetary measures taken by the US Treasury and Federal Reserve Bank, such as regulation $Q$, practically assured that dollars could not be brought back to the US. Some clever bankers then started putting these non-returnable dollars - that is dumpies - to use and the euro-dollar market was born. By the end of 1973 the gross size of the euro-currency market was estimated at $\$ 305$ billion by Morgan Guaranty Trust. The end of March 1979 figure was $\$ 915$ billion. Approximately $75 \%$ of these funds represents euro-dollars.

In concluding this section on the breaking down of the discipline of the international payments system, it may serve a useful purpose to compare the current status with the three main objectives of the ideal system as initially stated: Does it allow national economies to grow at optimum, sustainable rates? Does it put a realistic market value on national currencies? Does its stability enhance world trade? In my book the answer to all three questions is an unequivocal NO!

\section{Rising inflation}

Inflation, after being kept dormant in the fifties and sixties, reached double digit figures in virtually every country in the Western world sometime in the middle seventies. Undoubtedly the oil price increases had an influence on price levels, but it is argued in this paper that they have simply been grafted onto existing, ingrained inflation.

The root cause of today's inflation is undoubtedly to be found in the explosion in world liquidity as described above. To those who would like to argue this point, may we pose this question: Suppose the rest of the world could, and would say to all the unwanted dollars in the system: Yankee go home! Suppose American Banks were suddenly flooded with this amount of paper money? What would happen to inflation in the United States? Your guess is as good as mine as to the extent of the price explosion such an influx would trigger off. Now for the next question: If it is agreed that the USA would not be able to cope with the excesses of its own printing press, how can it be argued that that very same paper is noninflationary to the rest of the world? Once there is agreement on this principle, we can start arguing the next point which centres around the question of degree.
The above does not imply that the Americans should solely be blamed for all the world's inflationary ills. Was not the rest of the world, with a few exceptions, only too eager to accept euro-dollar loans to tide them over balance of payments deficits?

This paper does not argue that the dollar explosion in world liquidity was per se the cause of the subsequent inflation; rather that it created the permissive international monetary framework wherein inflation was allowed to breed with impunity. Governments could at the wrong time follow expansionary domestic policies (like the 1971 US budget); and trade unions could not be frightened off with the dire consequences of balance of payments deficits for job creation (a country in trouble could always borrow or devaluate its currency). In short, under the new set of circumstances pertaining in the seventies, the early evils of inflation became camouflaged under a cloak of apparent goodliness and hence inflation was allowed to take root.

The scope of this paper does not permit an academic discussion of the relationship between inflation and economic growth. Suffice to say that the realities of the seventies have sadly disillusioned those who believed that one could buy growth with inflation.

In a recent interview with The Economist, Helmut Schmidt echoed these sentiments: 'We were also the first to understand that you cannot cure the world's economic structural crisis by printing money. We'll not give up our conviction in that field. Others are on the verge of giving it up, some don't have the strength to do it although they understand its being necessary. No, we will not accept wrongly-so-called Keynesian recipes for a totally nonKeynesian situation'.?

Allow me to single out only one of the many pernicious effects of inflation, namely on the investment decision. Businessmen know that even modern day accounting methods do not always tell them the exact state of their affairs. They do not know what their true profits are, because they do not know what their replacement costs will be. They perceive that they do not know exactly where they are going. Hence uncertainty increases and the risk factor multiplies. There is a hesitancy to commit funds to fixed capital outlays, despite perhaps projected huge paper profits. One of the most perturbing aspects of the seventies is that fixed investment is not taking place at a sufficient rate to ensure sustained future growth and employment. In many countries of the world (South Africa included), the per capita levels of real fixed investment are now lower than in the early seventies.

\section{The oil crisis}

Oil currently provides more than $50 \%$ of the world's energy needs and there has been an exponential rise in oil consumption during this century. More than $55 \%$ of the world's known oil deposits are located in the Middle East.

After World War II, the West's strategy to keep this life-line open was more or less one of tacitly leaving it to the Big Seven (Esso, Gulf, Mobil, Standard, Texaco, BP, Shell and later CFP), plus some diplomatic appeasement, string pulling and other forms of undercover operations. The first crack in the wall appeared with the establishment in 1951 of the National Iranian Oil Co. (NIOC) as 
local refiner and equal partner in joint producing ventures. Subsequently, OPEC was created in September 1960 by the major Middle East producing countries plus Venezuela and Indonesia. During the late sixties power had shifted from the side of the oil companies to that of the host governments in the oil exporting countries. During late 1973 OPEC could enforce a fivefold increase in the posted price of crude. Although the 1973 decision was triggered off by political developments, it must be remembered that the power shift and subsequent cohesion in OPEC ranks were consequences of the pressures on supply, of soaring world demand. During 1974 OPEC enjoyed a current account surplus of $\$ 68$ billion dollars with the rest of the world, compared with only \$6 billion during the preceding year. By 1978 this surplus had again dwindled to $\$ 6$ billion and what happened? Another $60 \%$ price hike in 1979! The IMF estimates that OPEC's surplus this year should be back to $\$ 45$ billion. From the above it would appear that it is not Allah who is manipulating the price of oil, but economic laws of supply and demand, admittedly in an imperfect market!

The effects of these sudden price hikes are neatly summed up in a recent GATT report (1979):

'The conclusion that the oil price increase will be inflationary is frequently based on the assumption that, once the increases in petroleum product prices have been added to the underlying rate of inflation, the new and steeper inflationary trend will be fully incorporated into wage settlements. This is, indeed, a considerable risk in the present situation. The petroleum price increase represents an adverse movement of the terms of trade of the importing countries. There is thus some loss of real income . . . for each of these countries; this loss can be made up by subsequent growth, but cannot be prevented or avoided. Attempts by particular groups to protect their members against this loss, and thus to shift the burden onto other sections of society, are bound to be seif-defeating. Increases in money wages calculated to offset the terms of trade loss must have one of two undesirable effects. Either the central bank stands firm, in which case there is an increase in unemployment, or else monetary policy is eased in order to "validate" the excessive increase in money wages - thereby adding another twist to the inflationary spiral which, in the end, will cause a much greater loss of income - through slower growth or even an absolute decline - than the original terms of trade shift'. Of importance to note here are the steps in the vicious circle:

- A permanent oil price increase means a permanent shift in the terms of trade and a proportionate reduction in the wealth of consumer nations.

- This de facto decline is unlikely to be accepted without actions by countries or groups to protect themselves. The actions by countries would include recourse to the recycling mechanism, 'beggar they neighbour' trade policies and devaluations. The actions by groups (such as labour unions or medical associations) to protect their members, must in the end be self-defeating, 'adding another twist to the inflationary spiral'.

- The end-result is a further weakening of the dollar, the unit of currency in which the oil price is expressed. A decline in the dollar value is a handy excuse for a further hike in the price of oil and the whole process becomes self-perpetuating!

The cardinal problem is that oil-using countries took the easier course of using the financial and commercial recycling process to adapt to this new situation, rather than restructuring their own life styles to use less energy. Financial and commercial recycling took the form of borrowing OPEC's surplus petrol dollars, and selling more goods and services to OPEC. The industrial countries were in a more advantageous situation to employ this strategy and thus the gap between the rich and the poor countries grew bigger. The accumulated deficits on current account of the developing countries amounted to the staggering sum of $\$ 146$ billion for the four year period 1974 to 1978 and inflation is rampant at an average $30 \%$ per annum. Another horrific deficit of $\$ 40$ billion is forecast by the IMF for 1979. These deficits have largely been financed through the private commercial banking system (IMF standby credits had too many strings attached). At present no attempts are being made to deflate the balloon; crisis measures have only one object - to keep the candle away.

Losing the strategic military initiative to the East During the Cuban missile crisis of the early sixties, Russia had to withdraw and Kruschev lost face. This time around $\mathrm{Mr}$ Carter has simply been rebuffed by Moscow and has had to accept the unacceptable and adapt to it. As stated in The Economist:" 'At a time when American foreign policy anyway appears to be adrift and when the dollar is in such a plight that the chairman of the Federal Reserve Board has to scramble away from the IMF's annual meeting three days early, with the secretary of the treasury in hot pursuit, the United States could well do without such a display of national impotence'. The article continues: 'The affair has demonstrated both the extent to which America's ability to put pressure on Russia has diminished, compared with a few years ago, and $\mathrm{Mr}$ Carter's willingness to use even those means of pressure he still has ... For Russia the desirable thing about $\mathrm{Mr}$ Carter is his malleability, the undesirable thing is his incoherent way of running a government; and the second may be starting to loom larger than the first'.

This incident is merely cited as an example of how the super diplomatic power of the United States has waned in the wake of its decline as super military power. I can do no better than conclude this section of this paper with a few brief quotations from Dr James Schlesinger's farewell speech to the National Press Club in Washington on 16 August 1979.

'The strategic vortex of the crisis now lies on the Persian Gulf and adjoining areas of the Middle East, with their vast reserves of oil. Thus it is focused on a region which is politically volatile, characterized by historical animosities and by nation states whose social structures are not yet fully equipped to withstand the buffets of rapid political, economic and social change. And yet, the West, all free nations, indeed freedom itself, remain for the immediate future, dependent upon access to the oil resources of this volatile region... .

'In the light of subsequent development it (NATO) is today an insufficient basis for Western security, since in itself it offers no protection for the energy resources on which our collective survival depends'. 


\section{The eighties}

During the second part of this paper, attention was focused on four interrelated economic shocks that vibrated through our economic system: the disintegration of a stable international payments system, the eruption of violent worldwide inflation, the tenfold increase in oil prices and the apparent debility of the West's strategic influence.

At the outset it was motivated why the year 1974 was chosen as the artificial vantage point, from which firstly to look back, and, secondly, also to look forward. What has happened on these four fronts in the interim period (that is between 1974 and 1979) does not encourage optimism for the eighties.

On the international payments front, the patch work has continued and the amplitudes in the fluctuations in currency values have grown bigger. Or as The Economist summarized the most recent IMF proceedings: "The most positive decision taken jointly by 138 National delegations of finance ministers and central bankers in Belgrade was to say boo to the Palestine Liberation organization'.

Regarding world inflation, we have the persistent upward spiral amidst pious promises that everything possible is being done to combat public enemy number one. Here again we have Helmut Schmidt's chilling accusation that some are on the verge of giving up the struggle, while others do not have the strength to do what they know to be necessary.

As for oil prices, we saw what happened when OPEC's trade surplus in 1978 dwindled to its pre-1974 low of \$6 billion: prices were increased by $60 \%$ in order to get that surplus up again to $\$ 40$ billion plus.

Concerning the West's strategic position during the past five years, we can only see a further deterioration.

Having positioned our vantage platform on these four rather crumbling pillars, it would call for a supreme optimist to predict a brave new world for the eighties.

\section{What ought to be done}

Maybe we should start by examining what ought to be done and then decide what the outcome will be. We again take three of the four points.

\section{International payments system}

Regarding the international payments system, a measure of stability should be created. This means a return to old values where a balance of payments surplus should be considered a virtuous achievement and a deficit the result of national over-indulgence. Some semblance of the discipline of Bretton Woods will have to return, whereby countries are forced to abolish the pursuit of national policies which are harmful to the international economy. And, when all the shouting has died down, there remains only one disciplinary force that can play this role - that barbaric metal, gold. Can we see that happen?

\section{Controlling inflation}

Only when some control over the expansion of international liquidity can be effected, will it be possible to harness the forces of inflation. But even then a difficult road lies ahead, a road where national budgets must balance. This implies levels of government expenditure much lower than those currently prevailing in many countries around the globe. The United States is a prime example of how a country should not run its domestic budget. You need not consider this as authority, but that of a former secretary of the US Treasury, William Simon. The main message of his spine-chilling book, 'A Time for Truth' ${ }^{4}$ is that, like New York, the United States itself is on its way to bankruptcy, if it continues to run up those huge fiscal deficits. And at stake with the United States is the free western world.

\section{Energy}

On energy the equation is quite simple. The chairman of SASOL, Dr Dawid de Villiers, recently put it in this way: 'Ordinary man can at any one moment produce only a fraction of one horse-power, while he has readily at his ' disposal, on average approximately $5000 \mathrm{hp}$.' And much of that 5000 originates in the Middle East. There is really only one way to get out of this vicious circle. Consume less oil. The real tragedy of the past five years is that the West has not learned this lesson. They have been satisfied with the re-cycling of petro-dollars, not realizing how they are spinning the spider's web ever closer. When will the greatest oil importing country in the world, the United States, start with a viable oil conservation policy? Only then will I become more optimistic about international economic prospects for the 1980's.

\section{Final word}

Up to this point I have refrained from referring to the South African situation, but at times the temptation to boast just a little became almost overwhelming. Our watershed year did not come in 1974 - we then enjoyed our biggest boom in history - but only two years later, when for us the chickens also came home to roost.

Since 1976 we have been following a policy of financial discipline and we have reaped the fruits thereof in the biggest swing into surplus in the history on our balance of payments. Naturally we had to sacrifice growth, but growth of a nature we could do well without.

Fiscal hardship has, as yet, not made that dent on inflation that we would have liked to see. Neither do I think that we shall be able to completely isolate ourselves from the fresh tidal wave of international inflation that the eighties hold in store for us.

But we have turned our backs on the philosophy of government regulation and have rediscovered the discipline of the market mechanism. This may prove to have been a pivotal choice for the eighties.

Above all, however, we are firmly set on a path of energy self-sufficiency.

For these reasons, I firmly believe that even though the South African economy will not escape the vibrations of the shock waves of the eighties, the vessel is seaworthy enough not only to remain afloat, but to pass many other ships and debris; on a course that may yet prove the envy of many nations.

\section{References}

1. KAHN, HERMAN. The next 200 years. William Morrow \& Co, Inc. New York. 1976.

2. THE ECONOMIST. 1979-09-29.

3. THE ECONOMIST. 1979-08-4.

4. SIMON, W.E. A time for truth. Reader's Digest Books, McGraw Hill, New York. 1978. 